\title{
RELASI KEKUASAAN DALAM WACANA PENERAPAN QANUN JINAYAT DI ACEH
}

\author{
Putri Maulina \\ Program Studi Ilmu Komunikasi, Universitas Teuku Umar \\ Email: Putrimaulina.lecturer@gmail.com
}

\begin{abstract}
Implementation of Islamic Sharia in Aceh not only involve to the Muslim society as the majority, but also non-Muslim minority society. One of the laws that applied in Aceh is Qanun Jinayat. Implementation of Qanun Jinayat as part of the Islamic law involving multiple parties in a relationship of power. In this case, the Aceh government and the mass media are the 'power' which determines the dominant discourse in the society. This qualitative study will describe how thus power manifested in such discourse of the media. Eventually, the result of study showed that the issue of enforcement of Qanun Jinayat takes the interests of the dominant ruler through the uses of language in the media
\end{abstract}

Keywords: Power Relations, Govermentality, Sharia Law, Qanun Jinayat

\section{PENDAhuluan}

Aceh merupakan salah satu provinsi di Indonesia yang memiliki masyarakat mayoritas muslim. Selain masyarakat Islam sebagai mayoritas, di Aceh juga terdapat masyarakat beragama minoritas seperti masyarakat Kristen, Hindu, dan Budha. Keberadaan masyarakat beragama minoritas di wilayah hukum syariat Islam seperti ini tentu saja menjadi tantangan bagi proses demokrasi di Aceh. Terlebih lagi jika berkaitan dengan penerapan syariat Islam, salah satunya seperti wacana pemberlakuan Qanun Jinayat.

Sebagai daerah yang memiliki otonomi khusus, Aceh memiliki kewenangan tersendiri dalam membuat kebijakan-kebijakan yang berbeda dari provinsi lainnya di Indonesia. Maka pada 27 September 2014 lalu Dewan Perwakilan Rakyat Aceh (DPRA) secara resmi mengesahkan Rancangan Undang-Undang Qanun Jinayat menjadi Undang-Undang Qanun Jinayat sebagai patokan penyelenggaraan hukum di Aceh. Qanun Jinayat adalah suatu hukum terhadap bentuk perbuatan kejahatan yang berkaitan dengan pembunuhan, perzinaan, menuduh zina, pencurian, mabuk, dan lain-lainnya yang berlandaskan pada syariat Islam. Adapun sanksi bagi para pelanggar hukum tersebut meliputi Qishash, Hadd, dan Ta'zir. Di Aceh hanya ada beberapa hukum Jinayat yang diberlakukan dan ditindaklanjuti dengan menggunakan hukum Hadd dan Ta'zir, yaitu Qanun Jinayat No.12 Tahun 2003 tentang Khamar, Qanun Jinayat No.13 Tahun 2003 tentang Maisir; dan Qanun Jinayat No.14 Tahun 2003 tentang Khalwat.

Media massa dalam hal ini memiliki kekuasaan untuk menyebarkan informasi dan membentuk opini publik terhadap suatu isu yang sedang berkembang di masyarakat. Abrar (2011: 90-92) menjelaskan bahwa media massa berperan besar dalam menjaga demokrasi dan pluralisme khususnya dalam menyediakan ruang untuk menyalurkan pendapat-pendapat masyarakat beragama minoritas di Aceh, juga menjaga keseimbangan pemberitaan untuk mencegah munculnya konflik. Media dalam hal ini memiliki kuasa untuk mengkonstruksi realita dan membangun persepsi khalayak mengenai wacana pengesahan Qanun Jinayat yang juga 
diberlakukan terhadap masyarakat non-muslim. Sudut pandang yang digunakan media dalam memberitakan pihak-pihak minoritas memiliki pengaruh terhadap posisi mereka di tengah-tengah masyarakat mayoritas muslim di Aceh.

Proses pengesahan Rancangan Undang-Undang Jinayat menjadi Undang-Undang Hukum Jinayat pada 27 September 2014 menjadi polemik dan perdebatan dari berbagai kalangan baik di Aceh dan di luar Aceh, yaitu mengenai kelayakan beberapa pasal untuk ditetapkan sebagai perangkat hukum yang mengikat masyarakat Aceh. Salah satunya adalah mengenai keberadaan beberapa pasal yang juga diberlakukan kepada kalangan beragama minoritas selain Islam yang ada di Aceh. Seperti di dalam Pasal 5 huruf (b) "Setiap orang beragama bukan Islam yang melakukan jarimah di Aceh bersama-sama dengan orang Islam dan memilih serta menundukkan diri secara sukarela pada Hukum Jinayat"; dan (c) "Setiap orang beragama bukan Islam yang melakukan perbuatan jarimah di Aceh yang tidak diatur dalam Kitab Undang-Undang Hukum Pidana (KUHP) atau ketentuan pidana di luar KUHP, tetapi diatur dalam Qanun ini".

Media massa menjadi perpanjangan tangan pemerintah dalam mengusung isu penerapan Qanun Jinayat terhadap masyarakat Aceh secara keseluruhan. Oleh karena itu, media tidak bisa terbebas dari nilai-nilai dan ideologi di dalam pemberitaannya. Bagaimana kekuasaan dominan ditanamkan di dalam pemberitaan mengenai penerapan Qanun Jinayat tersebut tergantung pada pembingkaian yang dilakukan oleh media terhadap berita yang diproduksinya. Posisi masyarakat beragama di Aceh terkait dengan Qanun Jinayat tersebut, dapat dipengaruhi oleh kekuasaan yang ditanamkan oleh media.

\section{KERANGKA TEORI}

\section{Konstruksi Realitas di Media Massa}

Realitas mengenai kebijakan penerapan Qanun Jinayat di Aceh yang dibangun dalam pemberitaan media massa pada dasarnya adalah hasil konstruksi atas realitas. Berdasarkan pandangan Berger dan Luckman mengenai konstruksi sosial atas realitas, di dalam kehidupan sehari-hari realitas sosial memiliki dimensi obyektif dan subyektif. Proses terbentuknya realitas sosial adalah suatu proses dialektika manusia sebagai produk masyarakat dan masyarakat sebagai produk manusia, tercipta dari tiga unsur yaitu obyektivasi, internalisasi, dan eksternalisasi (Novianti, 2007: 116). Maka, dalam hal ini media juga berperan besar dalam mengkonstruksi suatu realita sosial sebagai proses dialektika suatu masyarakat.

Serambi Indonesia dalam mengkontruksi realitas tentang penerapan Qanun Jinayat di Aceh tersebut, tentu saja tidak terlepas dari berbagai kepentingan. Seperti yang dijelaskan oleh Eriyanto (2002: 26) bahwa media bukan sekedar saluran yang bebas, menjadi subjek yang mengkonstruksi realitas dan secara aktif menafsirkan realitas tersebut untuk disajikan kepada khalayak, tidak terlepas dari kecenderungan pemihakannya juga bias dan penonjolan-penonjolan terhadap fakta tertentu.

Realitas yang dibangun oleh media jika dipandang dalam perspektif konstruksionis bersifat subjektif yang hadir karena subjektifitas wartawan, yang tercipta lewat konstruksi dan pandangan tertentu sehingga realitas tersebut akan dipahami berbeda-beda oleh wartawan (Eriyanto, 2002: 22). Dari sudut pandang konstruksionis, Serambi Indonesia memiliki pandangan, bias, dan juga pemihakannya. Dapat dilihat dengan penempatan sumber berita yang menonjol dibandingkan dengan sumber yang lain, liputan yang hanya satu sisi dan merugikan pihak lain, tidak berimbang dan secara nyata memihak kelompok tertentu. Hal tersebut tidak lah dianggap sebagai suatu kekeliruan atau bias tetapi dianggap memang seperti itulah praktik yang dijalankan oleh wartawan. Eriyanto (2002: 26) menjelaskan bahwa media dipandang sebagai agen konstruksi sosial yang mendefinisikan realitas, sehingga media bukanlah sebagai tempat saluran yang bebas dari berbagai kepentingan. 
Jadi berita apapun yang didapatkan dari media Serambi Indonesia tersebut bukan hanya menunjukkan realitas, namun juga menunjukkan bagaimana konstruksi dari media tersebut. Seperti yang dijelaskan oleh West dan Turner (2008: 187) bahwa dalam pandangan konstruksionis, yang difokuskan adalah bagaimana suatu realitas politik dan sosial dibentuk oleh media. Isi media merupakan hasil praktisi media mengkonstruksi berbagai realitas yang dipilihnya berdasarkan ideologi dan kognisi sosial wartawan. Dengan demikian seluruh isi media tiada lain adalah realitas yang telah dikonstruksikan menjadi sebuah berita bermakna yang disajikan kepada publik (Hamad, 2004: 11).

\section{Govermentality sebagai Bentuk Relasi Kekuasaan}

Kepentingan yang bermain-main di dalam pemberitaan Serambi Indonesia terkait dengan isu penerapan Qanun Jinayat di Aceh tersebut, tidak terlepas dari pengaruh kekuasaan. Maka untuk mengkaji permasalahan ini dapat dilihat dengan menggunakan pandangan Michel Foucault tentang kekuasaan. Foucault memperkenalkan suatu konsep tentang "governmentality" di dalam pandangannya tentang relasi kekuasaan (power relation). Menurut Lemke (2000: 4) governmentality merupakan suatu konsep kekuasaan yang digunakan oleh Foucault untuk mempelajari kapasitas otonom individu dalam melakukan kontrol diri dan bagaimana hal itu berkaitan dengan politik negara. Digunakan untuk menyelidiki bagaimana hubungan antara teknologi diri (power from below) dengan teknologi dominasi (power from above) yang dapat mewujud dalam setiap relasi sosial (Mudhoffir, 2013: 97).

\section{METODE PENELITIAN}

Kajian ini bersifat kualitatif deskriptif, menggunakan metode analisis framing dengan pendekatan konstruksionis. Penggunaan analisis framing ini adalah berusaha untuk membongkar bagaimana pengaruh ideologi dominan yang ada dibalik pemberitaan media Serambi Indonesia tersebut. Sedangkan kajian kualitatif adalah suatu kajian yang menghasilkan prosedur analisis yang tidak menggunakan prosedur analisis statistik. Bertujuan untuk menjelaskan fenomena dengan sedalam-dalamnya melalui pengumpulan data dan analisis yang mendalam (Kriyantono, 2006:56). Hasil dari kajian ini bersifat deskriptif, yaitu dengan memberikan gambaran bagaimana Serambi Indonesia mengkonstruksi isu penerapan Qanun Jinayat dan pluralisme di Aceh juga membongkar bagaimana ideologi dominan tercermin dalam teks berita tersebut.

Untuk melihat bagaimana konstruksi realitas tentang isu penerapan Qanun Jinayat terhadap posisi masyarakat beragam minoritas di Aceh dan kepentingan kekuasaan dominan di dalam media, maka dapat dianalisis dengan menggunakan analisis teks media yang dikenal sebagai analisis framing. Sobur (2001: 162) menjelaskan bahwa analisis framing digunakan untuk mengetahui bagaimana perspektif yang digunakan wartawan ketika menyeleksi isu dan menulis berita. Perspektif itu pada akhirnya menentukan fakta apa yang diambil, bagian mana yang ditonjolkan dan dihilangkan serta ideologi apakah yang lebih cenderung ditampilkan dalam pemberitaan.

Dalam penelitian ini penulis menggunakan perangkat framing model Zhongdang Pan dan Gerald M. Kosicki untuk sebagai alat dalam membedah teks pemberitaan pada Serambi Indonesia. Ada tiga elemen analisis yang digunakan dalam model ini, yaitu: pertama adalah sintaksis (cara wartawan menyusun fakta) yang mengamati skema berita; kedua adalah skrip (cara wartawan mengisahkan fakta) yang mengamati alur dan kelengkapan isi berita; ketiga adalah tematik (cara wartawan menulis fakta) yang mengamati dari sisi detail, maksud kalimat, nominalisasi antar kalimat, koherensi, bentuk kalimat, serta bentuk kata ganti di dalam berita; dan keempat adalah retoris (cara wartawan menekankan fakta) yang dilihat dari penggunaan leksikon, grafis, metafor, dan pengandaian dalam berita (Sobur, 2001 : 176). 
Tabel 1: Sumber Data

\begin{tabular}{|l|l|}
\hline \multicolumn{1}{|c|}{ Edisi } & \multicolumn{1}{c|}{ Judul } \\
\hline Minggu, 28 September 2014 & $\begin{array}{l}\text { "Bukan Hanya Sekedar Qanun", "Disosialisasikan } \\
\text { dengan Baik" }\end{array}$ \\
\hline Senin, 29 September 2014 & "Sosialisasi Kunci Sukses Qanun Jinayat" \\
\hline 10 Oktober 2014 & $\begin{array}{l}\text { "Qanun Jinayat Efektif Berlaku 28 September } \\
\text { 2015" }\end{array}$ \\
\hline
\end{tabular}

Sumber: Olahan Peneliti

\section{HASIL DAN PEMBAHASAN}

Konstruksi Serambi Indonesia Terhadap Pemberitaan Pengesahan Qanun Jinayat di Aceh.

Salah satu fungsi media massa adalah memberikan informasi pada khalayak. Dalam proses peliputannnya, kebijakan redaksional, kondisi sosial, kearifan lokal, dan pertimbangan respon pasar akan mempengaruhi pemilihan informasi yang disajikan. Media memiliki perspektifnya tersendiri dalam mengkonstruksikan suatu realitas untuk disiarkan menjadi pemberitaan kepada khalayak.

Serambi Indonesia adalah salah satu media lokal yang memiliki kedekatan dengan masyarakat Aceh. Sejak pengesahan UU Qanun Jinayat di Aceh pada 27 September 2014, jika dianalisis dari sisi sintaksis Serambi Indonesia lebih sering mengangkat judul pemberitaan yang pro penerapan Qanun Jinayat, bukan mengenai tanggapan warga beragama minoritas terhadap pengesahan qanun tersebut. Adapun sumber yang digunakan oleh Serambi Indonesia adalah dari pihak pemerintah terkait seperti pihak Dinas Syariat Islam dan DPRA, dengan menggunakan latar informasi tentang sosialisasi dan ketegasan pemerintah untuk menerapkan Qanun Jinayat di Aceh. Sumber dari warga agama minoritas tidak disertakan di dalam pemberitaan.

Sedangkan dari sisi analisis skrip, Serambi Indonesia meniadakan unsur "who" yang mewakili pihak agama minoritas sebagai narasumber berita dengan lebih menonjolkan posisi dan pendapat dari pemerintah terkait. Kecenderungan Serambi Indonesia yang mengabaikan pendapat warga beragama minoritas di Aceh tersebut, justru dapat melemahkan posisi mereka terhadap isu penerapan Qanun Jinayat di Aceh. Serambi Indonesia juga tidak menonjolkan pada unsur "how" pemberitaan, yang menjelaskan tentang bagaimana reaksi dari warga agama minoritas terhadap proses pemberlakuan qanun tersebut. Sehingga ada kedangkalan informasi bagi warga Aceh yang beragama minoritas terhadap proses dan tata cara pemberlakuan Qanun Jinayat, khususnya terhadap kalangan warga minoritas seperti non-muslim.

Analisis tematik terhadap isi pemberitaan Serambi Indonesia, dapat diinterpretasikan bahwa Qanun Jinayat tersebut tidak menjadi suatu suatu permasalahan bagi umat beragama di Aceh, khususnya masyarakat yang beragama minoritas selain Islam. Penekanan dari kalimat-kalimat dalam pemberitaan di Serambi Indonesia tersebut secara jelas memposisikan penerapan Qanun Jinayat sebagai kebijakan yang benar, baik bagi warga muslim ataupun non-muslim Aceh. Pembingkaian realitas yang dilakukan Serambi Indonesia dengan jelas mendukung kebijakan pemerintah terhadap pengesahan Qanun Jinayat di Aceh, dengan menanamkan ideologi masyarakat dominan dan menggambarkan qanun tersebut sebagai aturan yang juga layak diberlakukan kepada masyarakat agama minoritas. Penegasan tersebut dilakukan dengan menghadirkan pernyataan dari Dermawan yang seorang muslim, tanpa turut menghadirkan pendapat dari pihak selain muslim. Berikut adalah kutipan dari Serambi Indonesia edisi 28 September 2014 : 
...dan dalam implementasinya nanti bisa memberi kesejukan dan keamanan bagi masyarakat, dan meski di dalamnya hukuman ini juga berlaku untuk masyarakat bukan Muslim, tetapi ini bukan hal yang buruk dan tidak akan menjadi masalah bagi umat beragama di Aceh," ujar Dermawan (Serambi Indonesia, edisi 28 September 2014).

Berdasarkan analisis retoris dalam pemberitaan pilihan kata yang digunakan dalam kutipan teks berita Serambi Indonesia seperti "non-muslim", "beragama bukan Islam", "bukan hal yang buruk dan tidak akan menjadi masalah", "memilih serta menundukkan diri secara sukarela pada hukum Jinayat", secara langsung dan tidak langsung dapat membungkamkan posisi warga beragama non-muslim untuk mengikuti dan menerima begitu saja realitas yang dikonstruksikan oleh media tersebut. Seperti dalam kutipan pemberitaan Serambi Indonesia lainnya :

“...terlebih karena yang menjadi subjek hukum di dalam qanun ini bukan cuma umat Islam di Aceh, tapi dalam hal-hal tertentu mencakup pula non-muslim" (Serambi Indonesia, edisi 29 September 2014).

Warga non-muslim di Aceh diarahkan untuk dapat berpartisipasi terhadap kebijakan Qanun Jinayat yang juga diberlakukan terhadap mereka, dan penglabelan sebagai "non-muslim" di dalam pemberitaan tersebut seakan-akan menunjukkan keminoritasan mereka ditengah-tengah mayoritas muslim sehingga dapat membuat mereka untuk mengikuti dan patuh terhadap kebijakan yang berlaku di wilayah tersebut secara bersama-sama.

\section{Governmentality dalam Wacana Penerapan Qanun Jinayat di Aceh}

Dalam pemberitaan ini, Serambi Indonesia mencoba menanamkan suatu kebenaran dari pandangan muslim sebagai masyarakat dominan dengan menggambarkan Hukum Jinayat tersebut sebagai aturan yang juga layak diberlakukan kepada masyarakat agama minoritas selain muslim. Penegasan tersebut dilakukan dengan menghadirkan pernyataan dari Dermawan yang seorang muslim, tanpa turut menghadirkan pendapat dari pihak selain muslim. Ini menunjukkan suatu bentuk kekuasaan pemerintah yang berorientasi Islam sebagai pihak mayoritas yang memposisikan masyarakat Aceh di luar agama tersebut sebagai pihak minoritas. Ruang berpendapat dan pembentukan opini di dalam berita juga cenderung memakai perspektif masyarakat Islam dominan. Meskipun demikian, di dalam pemberitaan tersebut Serambi Indonesia juga memberikan suatu penekanan bahwa masyarakat Aceh beragama minoritas memiliki hak untuk dapat secara bebas menentukan tindakan sesuai aturan Qanun Jinayat.

Terdapat kebenaran dominan yang dibangun oleh media sebagai hasil dari konstruksi atas realitas, bahwa Qanun Jinayat adalah layak diberlakukan pada setiap kalangan. Serambi Indonesia memiliki kuasa untuk membangun opini dan penglabelan positif terhadap kebenaran tersebut dengan membawa "kepentingan" dari pemerintah Aceh sebagai pihak yang berkuasa. Seperti yang dijelaskan oleh Foucault bahwa kebenaran diproduksi oleh pemikiran manusia, dan mengarahkan pada suatu bentuk kekuasaan (Danaher, Schirato, \& Webb, 2000: 26), dan dengan itu akan membentuk suatu regulasi diri terhadap kelompok sosial tertentu.

Pemerintah Aceh, menginginkan agar penerapan Qanun Jinayat dapat berjalan dengan lancar dan maksimal terhadap seluruh masyarakat beragama di Aceh. Maka dalam upaya menegakkan Qanun Jinayat yang disahkan pada 27 September 2014, pemerintah Aceh memanfaatkan media massa sebagai alat untuk pengawasan sosial. Relasi antara pemerintah dan media tersebut membentuk suatu relasi kekuasaan. Menurut Foucault, relasi kekuasaan tersebut terdapat dalam setiap relasi sosial, oleh karena itu kekuasaan tidak memusat dan tidak pula termiliki tetapi ia tersebar. Hal tersebut bukan karena kekuasaan merengkuh segalanya tetapi karena ia berasal dari manapun (Mudhoffir, 2013: 96). 
Upaya pemerintah Aceh menyebar kekuasaan tersebut, disebut sebagai governmentality yang dijelaskan di dalam konsep relasi kekuasaan Foucault. Pemerintah Aceh perlu mendorong masyarakat Aceh untuk tunduk dan patuh terhadap hukum Qanun Jinayat yang telah disahkan tersebut. Dan melalui governmentality kekuasaan pemerintah Aceh tentang pemberlakuan Qanun Jinayat diinternalisasi ke dalam tubuh sosial, yang mana subjek governmentality adalah masyarakat Aceh secara keseluruhan (Mudhoffir, 2013: 86). Serambi Indonesiakemudian menjadi relasi pemerintah melalui konstruksi pemberitaan yang dilakukan olehnya, dan menyebarkan hasil konstruksi kebenaran tentang pemberlakuan Qanun Jinayat bagi masyarakat Aceh. Maka baik warga Aceh yang beragama muslim dan tidak terkecuali warga non-muslim sebagai minoritas, menjadi objek dari penundukan tersebut. Pemerintah mengatur tindakan atau perilaku masyarakat dengan cara menginternalisasikan penundukan itu agar ia menjadi populasi yang patuh.

Lemke (2000) di dalam Mudhoffir (2013: 95) menjelaskan bahwa governmentality merupakan bentuk kontrol atau pengendalian diri (self-government) yang membentuk dan menghasilkan ranah kemungkinan pilihan tindakan subjek, kemudian memberikan banyak kemungkinan pilihan tindakan. Individu dalam kelompok sosial tidak merasa dirinya terpaksa atau tidak ada pilihan tindakan yang lain selain apa yang sudah ditentukan oleh kelompok dominan, melainkan secara potensial dalam diri subjek terdapat pengendalian atas praktik hidupnya sesuai dengan kontrol sosial yang dikehendaki oleh kepentingan politik pemerintah setempat. Artinya, masyarakat Aceh sebagai subjek dengan sendirinya akan memilih tindakan yang sebenarnya dikehendaki oleh pemerintah untuk menjalankan tindakan yang sesuai dengan hukum Qanun Jinayat. Dan masyarakat non-muslim Aceh dengan sendirinya mendapatkan pilihan-pilihan tindakan kemudian juga mengendalikan dirinya sendiri seperti kehendak dari kebijakan dari pemerintah Aceh.

Sebagai bentuk rasionalisasi beroperasinya kekuasaan, governmentality tidak lain dapat juga dipandang sebagai suatu cara yang sah dan benar dalam mengatur sesuatu. Ada beberapa kebenaran yang dikonstruksian oleh Serambi Indonesia tentang penerapan Qanun Jinayat di Aceh oleh pemerintah di dalam pemberitaan. Pertama, menurut pemerintah Qanun Jinayat dapat memberikan rasa aman bagi masyarakat Aceh dan dianggap baik untuk mengontrol berbagai penyakit sosial serta mengurangi kemaksiatan. Hal tersebut yang coba ditanamkan oleh pemerintah kepada masyarakat Aceh melalui relasi dengan media massa, sehingga dianggap sah dan benar. Penggambaran tentang hal-hal positif seperti ini memberikan pilihan tindakan bagi masyarakat Aceh, untuk bertindak seperti aturan dalam Qanun Jinayat yang dikehendaki oleh pemerintah.

Kedua, pengesahan Qanun Jinayat bagi masyarakat Aceh juga bagi masyarakat Aceh nonmuslim dianggap sebagai suatu kebenaran. Karena Qanun Jinayat tersebut dibentuk setelah mengalami proses yang rumit, melalui perdebatan dan pertimbangan yang panjang sehingga terbentuk kesepakatan bersama. Ditambah dengan penjelasan bahwa beberapa fraksi di DPRA telah sepakat untuk menyetujui pemberlakuan Qanun Jinayat tersebut di Aceh, Serambi Indonesia seakan-akan menunjukkan kepada khalayak bahwa pengesahan aturan tersebut benar-benar telah dipertimbangkan baik dan buruknya. Sehingga pada akhirnya layak diterapkan kepada masyarakat Aceh.

Dan ketiga, portal berita Serambi Indonesia menekankan suatu kebenaran lainnya sebagai bentuk penegasan. Bahwa dengan adanya sosialisasi yang baik, Qanun Jinayat tersebut akan sukses diterapkan bagi masyarakat Aceh keseluruhan. Dengan mengkonstruksikan realitas wacana seperti itu, kekuasaan menjadikan isu penerapan Qanun Jinayat diinternalisasikan dalam kelompok sosial dan dapat mengontrol khalayak secara lebih luas. Artinya, kekuasaan bisa memanifestasikan diri dalam bentuk kebenaran atau wacana yang lantas diinternalisasi dalam individu dan digunakan untuk memandu masyarakat Aceh dalam jumlah yang lebih luas. Begitu pula terhadap masyarakat Aceh yang beragama non-muslim.

Lebih lanjut, Jensen menjelaskan bahwa struktur sosial berlaku pada agensi manusia yang 
merujuk pada media dan menghasilkan suatu konstruksi sosial atas realita (Berger \& Luckmann, 1966). Maka permasalahan kebijakan hukum yang terkait dengan umat beragama menjadi tidak sesederhana reaksi langsung suatu individu atas struktur sosial namun harus lebih perhatian pada peranan dari wacana agama yang berkembang dengan realita-realita simboliknya (Hoover dan Lundby, 1997: 41-42).

Praktik seperti ini terlihat di Serambi Indonesia yang mana para jurnalis media tersebut didominasi oleh kalangan muslim, sehingga cenderung menggunakan perspektif Islam sebagai agama mayoritas di wilayahnya ketika menulis pemberitaan mengenai pengesahan Qanun Jinayat di Aceh dan lebih mendukung wacana kebijakan pemerintah. Perspektif dominan tersebut berpengaruh pada pesan dan simbol yang ditampilkan dalam teks pemberitaan tentang bagaimana kelompok non-muslim diposisikan, dilibatkan, dan diberikan ruang untuk menyampaikan pendapat mereka terhadap wacana pengesahan Qanun Jinayat di Aceh.

Masyarakat Aceh beragama minoritas di dalam pemberitaan ini diposisikan sebagai "defiyan" atau "the others" yang posisinya cenderung tidak ditonjolkan, sedangkan masyarakat Aceh muslim sebagai kalangan mayoritas. Posisi tersebut membuat masyarakat non-muslim juga terlibat dalam suatu aturan hukum yang sebenarnya bukan milik mereka. Namun di lain sisi, Serambi Indonesia menggambarkan suatu pilihan tindakan lain bagi warga minoritas di Aceh tersebut, bahwa Qanun Jinayat tersebut tidak bersifat memaksa untuk diterapkan oleh warga nonmuslim. Melalui konstruksi yang dibangun oleh media, menggambarkan bahwa ada suatu tindakan tertentu dapat menghadirkan ranah pilihan tindakan yang sangat terbuka bagi masyarakat non-muslim Aceh, tetapi mereka memilih tindakan yang sebenarnya dikehendaki oleh pemerintah.

Hasil konstruksi atas realitas Serambi Indonesia terhadap wacana Qanun Jinayat memiliki keberpihakan pada pemerintah Aceh, maka media tersebut juga memiliki kekuasaan untuk membangun pemberitaan bahwa Qanun Jinayat adalah layak diterapkan bagi masyarakat Aceh, dan kemudian mengarahkan kesadaran warga non-muslim untuk bertindak seperti apa yang dikehendaki oleh pemerintah tanpa melakukan pemaksaan dan mengnaturalisasikan hal tersebut.

Brian McNair memberikan pandangan bahwa sebuah berita merupakan a mediated version of reality (2006: 6), itu artinya adalah apapun yang disampaikan di media merupakan realitas bentukan media dan bukan yang sebenarnya. Apapun yang ditampilkan di media dikonstruksikan sesuai dengan nilai yang dianutnya dan konvensi kewartawanan. Maka oleh karena itu, kekuasaan pemerintah Aceh yang berorientasikan syariat Islam beserta seluruh proses-proses yang dilakukan oleh para praktisi media di Serambi Indonesia sangat memiliki kekuasaan untuk menyebabkan ketidakadilan dalam masyarakat dan menomorduakan masyarakat beragama minoritas (Sukardi, 2003: 131).

Permasalahan dominasi kekuasaan seperti ini secara lebih jelas digambarkan oleh Antonio Gramsci mengenai konsep hegemoni. Hegemoni merefleksikan suatu proses di mana nilai-nilai dari dominasi kelompok mayoritas dinegosisasikan, dikompromikan, dan mengubah kelompok minoritas melalui seluruh praktik-praktik sosial (Jones, 2006: 79). Gramsci melihat media sebagai sebuah ruang di mana berbagai ideologi direpresentasikan. Ini berarti, di satu sisi media bisa menjadi sarana penyebaran ideologi penguasa, jadi alat legitimasi dan kontrol atas wacana publik. Namun di sisi yang lain, media juga bisa jadi alat resistensi terhadap kekuasaan. Media massa bisa menjadi alat untuk membangun kultur dan ideologi dominan, sekaligus juga bisa menjadi instrumen perjuangan bagi kaum tertindas untuk membangun kultur dan ideologi tandingan.

Ada upaya dari Serambi Indonesia untuk menghegemoni masyarakat, yaitu suatu kebenaran mengenai penerapan hukum jinayat yang juga diterapkan pada warga non-muslim, dan penggambaran tersebut akan dinaturalisasikan mereka sebagai suatu hal yang biasa. Serambi Indonesia di sini berupaya untuk terkesan berimbang, namun kecenderungannya memposisikan perspektif pemerintah yang mewakili pihak agama mayoritas sebagai sudut pandang dominan di dalam teks pemberitaan dan memarjinalkan pendapat dari warga Aceh selain beragama Islam tidak 
bisa dielakkan. Lebih lanjut, akan berdampak terhadap suatu bentuk penundukan terhadap masyarakat Aceh beragama minoritas mengenai apa yang dikonstruksi oleh media tentang penerapan aturan Qanun Jinayat tersebut.

\section{KESIMPULAN}

Terkait dengan isu penerapan Qanun Jinayat di Aceh, hasil analisis framing terhadap pemberitaan media menunjukkan bahwa Serambi Indonesia mendukung wacana pemerintah terhadap penerapan Qanun Jinayat di Aceh. Oleh karena itu, Serambi Indonesia masih belum memberikan ruang bagi masyarakat beragama di Aceh untuk menyampaikan pendapat di pemberitaan mengenai penerapan Qanun Jinayat. Di sisi lain, kebenaran yang dikonstruksikan oleh Serambi Indonesia bukanlah kebenaran mutlak, karena mewakili kebenaran pemerintah setempat. Hasil konstruksi media tentang wacana penerapan Qanun Jinayat tidak dapat menggeneralisasikan bahwa penerapan qanun tersebut dapat diterima secara keseluruhan oleh warga Aceh, khususnya warga agama minoritas. Konstruksi pemberitaan Serambi Indonesia lebih menonjolkan keberpihakan kepada pemerintah setempat, dalam hal ini menggambarkan bahwa terdapat bentuk relasi kekuasaan antara pemerintah dan media untuk menyebarkan kebenaran versi mereka terhadap masyarakat Aceh. Masyarakat beragama di Aceh, menerima bentuk-bentuk kekuasaan yang disebarkan oleh media tersebut sebagai suatu kebenaran.

\section{DAFTAR PUSTAKA}

Abrar, Ana Nadya. 2011. Analisis Pers: Teori dan Praktik. Cahaya atma Pustaka. Yogyakarta.

Eriyanto. 2002. Analisis Framing: Konstruksi, Ideologi, dan Politik Media. LkiS. Yogyakarta.

Hoover dan Lundby. 1997. Rethinking Media, Religion, and Culture. Sage Publications. London, New Delhi.

Hamad, Ibnu. 2004. Konstruksi Realitas Politik dalam Media Massa: Sebuah Studi Critical Discourse Analysis terhadap berita-berita Politik. Granit. Jakarta.

Jones, Steve. 2006. Antonio Gramsci. Routledge. London dan Newyork.

Kriyantono, Rachmat. 2006. Teknik Praktis Riset Komunikasi. Kencana. Jakarta.

McNair, Brian. 2006. Cultural Chaos: Journalists, News and Power in a Globalised World. Routledge. London, New York.

Sobur, Alex. 2001. Analisis Teks Media: Suatu pengantar untuk Analisis Wacana, Analisis Semiotik dan Analisis Framing. PT Remaja Rosdakarya. Bandung.

Sukardi, Imam. 2003. Pilar Islam Bagi Pluralisme Modern. Tiga Serangkai. Solo.

West, Richard dan Lynn H, Turner. 2008. Pengantar Teori Komunikasi: Analisis dan Aplikasi. PT: Salemba Humanika. Jakarta. 